\title{
尿中剝離細胞の細胞遺伝学的検索
}

\author{
染色体観察の意義について

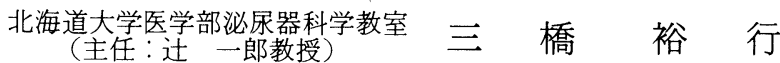

\section{CYTOGENETIC STUDY OF THE EXFOLIATED CELLS FROM UROTHELIAL TUMOR PATIENTS : \\ Observation of Chromosome of Exfoliated Cells}

Hiroyuki Mitsuhashi

Department of Urology, Hokkaido University School of Medicine, Sapporo, Japan

(Director: Prof. I, Tsuji)

In order to know biological property of urothelial tumor and to support urinary cytology, cytogenetic study was performed on exfoliated cells from 40 urothelial tumor patients and 23 no tumor patients with other urological disease. Among the tumor patients, 20 had superficial papillary (low-stage) bladder tumor, 16 had inveasive (high-stage) bladder tumor and 4 had ureter and renal pelvis tumor.

Cells, exfoliated in both urine and bladder washing fluid, were treated by a direct method using Colchicin.

Mitotic index (M.I.), incidence of dividing cells per 1,000 cells, was calculated, and chromosome analysis was achieved if adequate metaphase cells had been observed.

The results were as follows.

1) In the control patients the mean M.I. was extremely low. No metaphase cells were observed.

2) In the urothelial tumor patients, the mean M.I. was significantly higher and it increased according to histological grade and stage, and in some patients it decreased after irradiation.

3) Metaphase cells were observed in 14 low-stage bladder tumor, 10 high-stage bladder tumor and one renal pelvis tumor.

4) In the low-stage bladder tumor, 5 of 7 grade 0 tumor had only diploid or neardiploid cells, but 6 of 7 over grade I tumor had polyploid cells and one of them had marker chromosome.

5) Nine of 10 high-stage bladder tumor had polyploid cells and 4 of them had marker chromosomes. In conclusion, cytogenetic study of exfoliated cells provided a simple diagnostic aid for urothelial tumor.

要旨：尿路腫瘍の生物学的悪性度判定と尿細胞診を補正補助する目的で, 40 例の尿路腫瘍患者と23例の 他の泌尿器科疾患患者の尿中剝離細胞を用いて細胞遺伝学的検索を行なつた，尿路腫瘍40例のうち, 20 例が表在性乳頭状（low-stage）膀朕腫瘍，16例が浸潤性（high-stage）膀胼腫瘍，4例が腎孟尿管腫瘍 であつた。

尿中扰よび膀朕洗浄液中に剥離した細胞はColchicinを用いて直接法によつて処理した。

細胞1,000個あたりの分裂細胞頻度, Mitotic index (M. I.) を算定し, 適当な分裂中期細胞が認めら れた場合には，染色体分析を施行した。

1）対照例では平均 M. I. は極めて低値であり，分裂中期細胞は全く認められなかつた.

2）尿路腫瘍例では対照に比べて有意に平均 M. I. は高く, 組織学的 grade, stage に従つて高值を示し

た. 又いくつかの例では放射線療法後に M. I. の低下を認めた。

3）分裂中期細胞は log-stage 膀胱腫瘍14例, high-stage 膀朕腫瘍 10 例, 腎孟腫瘍 1 例に認められた.

4）low-stage 膀胼腫瘍では, grade 07 例中 5 例で 2 倍体又は 2 倍体附近の細胞のみを認め, grade 1 以上の 7 例中 6 例に polyploid の細胞を認め, 5ち 1 例に marker 染色体を認めた. 
5）10例中 9 例の high-stage 膀胱腫瘍で polyploid の細胞を認め，らち 4 例に marker 染色体を認め た.

これらの結果より，剝離細胞の細胞遺伝学的検索が尿路腫瘍の簡便な診断法となる事が示された.

\section{緒言}

尿路腫瘍, 特に low-grade, low-stage の膀胼腫瘍の の臨床経過, 予後はその組織学的異型度と必ずしも平 行しない1).

すなわち組織学的悪性度の低いと思われる乳頭腫や low-grade の乳頭状癌の中には再発を繰り返している らちにより悪性度の高い浸潤癌となつていくものがあ り,この様な症例を初診時の組織学的診断所見から予 測・鑑別することは出来ない。こうしたいわゆる生物 学的悪性度の高い腫瘍を早期に診断する方法の一つと して腫瘍細胞の染色体分析がある。

尿路腫瘍特に膀胼腫瘍の染色体分析は1967年の $\mathrm{Lamb}^{2)}$ の報告以来, 数多くなされているが, その大部 分は手術的に採取した腫瘍組織を材料とした研究であ る.

一方簡単に採取出来る尿中剝離腫瘍細胞を用いた染 色体分析の報告は少なく ${ }^{374)}$, またこの方法を通常の細 胞診の補正補助に用いたといら報告はない。

我々は数年来尿路腫瘍の染色体分析を試みている が，特に剝離腫瘍細胞に注目し，その分裂指数算定と 染色体分析が腫瘍の生物学的悪性度判定の一助とし て, どの程度利用出来るか否か，またこれと通常の尿 細胞診との関連性などについて検討した結果, 多少の 知見を得たので以下に報告する。

\section{対象}

1980 年 4 月より 81 年末要の北大病院泌尿器科入院 および外来患者のうち, 膀羘腫演 36 例, 腎孟腫瘍 2 例, 尿管腫瘍 2 例, 計 40 例（男子 31 例, 女子 9 例）の尿路 腫瘍患者を対象とした。

対照としては尿路腫瘍以外の各種泌尿器科疾患 23 例 （男子19例, 女子 4 例)を用いた. すべて成人例である.

\section{方 法}

イ。男子の自排尿，女子のカテーテル尿を用いた場 合と, 口. 導尿後生理食塩水 $50 \sim 100 \mathrm{ml}$ を膀脱内に注 入して数回 pumping した液を用いた場合とある.

直接法：低濃度の Colchicin $(0.2 \mu \mathrm{g} / \mathrm{ml})$ を直ちに 尿又は pumping 液に加光, $37^{\circ} \mathrm{C}$ で約 3 時間 incubate したのち, 1,500rpmで 5 分間遠沈, 上清をすて沈椬に $0.075 \mathrm{M}$ の $\mathrm{KCl}$ 溶液を加えて約 15 分間低張処理する. Carnoi 液（メチルアルコール 3：酢酸 1）を加えて,
$1,500 \mathrm{rpm}$ で 5 分間遠沈する操作を 3 回繰り返して細 胞固定する。上清をすて沈渣に適当量の Carnoi 液を 加えて細胞浮遊液を作り, 充分に脱脂したスライドガ ラス上に滴下し乾燥させる。 $70 \%$ チルアルコール中 に数十秒つけた後, Giemsa 液 (pH 6.8) で約 5 分間 染色をする. 又一部の症例ではスライドガラスをCarnoi 液で脱色後, Quinacrine 液を用いてQ-染色法を試 みた。

標本の観察に際してはまず弱拡大で細胞 1,000 個に 付き分裂細胞が何個認められるかを調べ，すなわち Mitotic index（以下 M. I.）を算定し，良好な分裂中 期細胞が認められた場合には強拡大で染色体数を算定 し必要に応じて写真撮影をする. 染色体数を算定出来 る細胞が 5 個以上あつた場合には，染色体数の mode を調べた。

短期培養法：一部の症例では Corchicin を加党ずに 沈渣細胞を抗生剤（ペニシリン，ストレプトマイシン 混合液）で洗浄後, 出来るだけ無菌的に培養液と牛血 清を加えて $\mathrm{CO}_{2}$-incubatorにて24〜72時間培養した 後, 前述の手順で染色体分析を試みた。

\section{結 果}

\section{I. 尿路腫瘍以外の対照疾患患者}

各症例の臨床 data は Table 1 に示したが, 全例尿 細胞診は陰性で内視鏡的に膀胱および尿道に腫瘍を認 めず, IVPでも上部尿路に腫瘍を疑わせる所見は認め られなかつた。

前立腺癌の 2 症例は肥大症として TUR 後, 組織診 断されたもので，尿道掞よび膀胱への浸潤は認められ なかつた。また腎癌の 1 例は完全に患側の腎機能が廃 絶しており顕微鏡的血尿も認めなかつたのでこれも対 照に加光た。

対照のらち尿路感染は急性 2 例, 慢性 7 例の計 9 例 （39\%）に認められた.

材料として自排尿ないしカテーテル尿を主に用いた が, 充分に剥離細胞が得られない場合には pumping を 行なつた。

豩離細胞の M. I. は 0 から 0.5 まで平均 $0.07 \pm 0.01$ と低く, また感染例は平均 $0.10 \pm 0.01$, 非感染例は

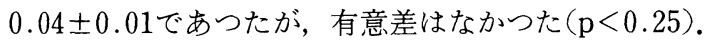
-Table 6 . 
Table 1 Clinical data (control patients)

\begin{tabular}{|c|c|c|c|c|c|}
\hline $\begin{array}{c}\text { Case } \\
\text { No. }\end{array}$ & Age & Sex & Clinical diagnosis & U.T.I. & M.I. * \\
\hline 1 & 71 & $\mathrm{M}$ & Prostatic cancer ${ }^{* *}$ & - & 0.5 \\
\hline 2 & 74 & $\mathrm{M}$ & B. P. H. & - & 0 \\
\hline 3 & 77 & $\mathrm{M}$ & B.P.H. & + & 0 \\
\hline 4 & 48 & $\mathrm{M}$ & Lt. renal stone & + & 0 \\
\hline 5 & 33 & $\mathrm{M}$ & Prostatitis & + & 0 \\
\hline 6 & 30 & $\mathrm{M}$ & Lt. ureteral stone & - & 0 \\
\hline 7 & 30 & $\mathrm{M}$ & Rt. ureteral stone & - & 0 \\
\hline 8 & 52 & $\mathrm{M}$ & Donor of renal transplant & - & 0 \\
\hline 9 & 63 & $\mathrm{M}$ & B.P. H. & + & 0 \\
\hline 10 & 75 & $\mathrm{M}$ & Prostatic cancer $* *$ & - & 0 \\
\hline 11 & 80 & $\mathrm{M}$ & B. P. H. & - & 0 \\
\hline 12 & 75 & $\mathrm{M}$ & B. P. H. & + & 0 \\
\hline 13 & 65 & M & B. P. H. \& bladder stone & + & 0 \\
\hline 14 & 58 & M & B. P. H. & - & 0 \\
\hline 15 & 59 & $\mathrm{M}$ & Rt. renal stone & - & 0 \\
\hline 16 & 66 & $\mathrm{M}$ & B. P. H. & - & 0 \\
\hline 17 & 72 & $\mathrm{M}$ & B. P. H. & - & 0 \\
\hline 18 & 57 & $\mathrm{M}$ & Blt. renal stone & + & 0 \\
\hline 19 & 76 & $\mathrm{M}$ & B. P. H. & + & 0 \\
\hline 20 & 58 & $\mathrm{~F}$ & Rt. renal bleeding & - & 0 \\
\hline 21 & 36 & $\mathrm{~F}$ & Acute cystitis & + & 0.5 \\
\hline 22 & 42 & $\mathrm{~F}$ & Acute cystitis & + & 0.5 \\
\hline 23 & 50 & $\mathrm{~F}$ & Rt. renal tumor & - & 0 \\
\hline
\end{tabular}

$*$ : mitotic index per 1000 cells, ${ }^{* *}:$ postoperative diagnosis

pumping 5 回を含めて計28回材料採取を行つたが, 剝離細胞に分裂中期細胞は全く認められなかつた。

\section{II. 尿路腫瘍}

尿路腫瘍全体の M. I. は平均4.13土0.59で，対照に 比べて有意に高く $(\mathrm{p}<0.005)$ ，かつ豩離細胞中に染色 体分析可能な分裂中期細胞 (以後分裂中期細胞とする) が計244個，1症例につき平均 9.9 個認められた。

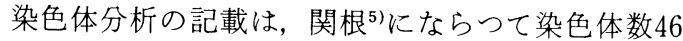
を有するものみ 2 倍体，69のものを 3 倍体，92のもの を4倍体といら様にし，これらの前後のものをそれぞ れ，低一，高一と，また前後にわたるものを一附近と 表現した. mode は染色体数の最頻のものであり, 前後 を含めて腫瘍の ploidyを判定した。

\section{A. 膀胱腫瘍}

34 例の膀胼上皮性腫瘍を表在性乳頭状腫瘍と浸潤癌
とに大別した。

\section{I. 表在性乳頭状腫瘍}

Table 2 に示したごとく全例 TUR で治療された乳 頭状腫瘍で, いずれも筋層内への浸潤を認めないlowstage のものである. 組織学的 grade は 0 度 (乳頭腫) 7 , I 度 11, II 度 2 となる. II 度の 2 例も腫瘍の大部 分はI 度で一部にのみ II 度の異型細胞構造を認めた ものである。

20 例中初発例が 9 例, 再発例が11例であり, 単発腫 瘍が 13 例， 2 個以上の多発腫瘍 7 例である。な括 6 例 はレ線学的に腫瘍による陰影欠損を認めたが，上部尿 路に腫瘍を疑わせる所見を認めた例はなかつた。

(a) 分裂中期細胞の発見率：染色体分析は全て直接 法を用いて行ない20例中14例（70\%）に分裂中期の剝 離細胞が認められた。 
Table 2 Clinical data (low stage bladder tumor patients)

\begin{tabular}{|c|c|c|c|c|c|c|c|c|c|}
\hline $\begin{array}{c}\text { Case } \\
\text { No. }\end{array}$ & Age & Sex & $\begin{array}{c}\text { Histology } \\
\text { (grade) }\end{array}$ & $\begin{array}{c}\text { Cytology } \\
\text { (class) }\end{array}$ & M.I. * & $\begin{array}{l}\text { Primary or } \\
\text { recurrence }\end{array}$ & $\begin{array}{l}\text { Multiple } \\
\text { or single }\end{array}$ & \begin{tabular}{|l|}
$\begin{array}{l}\text { Shadow } \\
\text { defect }\end{array}$ \\
\end{tabular} & Treatment \\
\hline 1 & 59 & $\mathrm{M}$ & I & $\mathrm{V}$ & 1 & $\mathrm{P}$ & M & + & TUR \\
\hline 2 & 58 & $\mathrm{M}$ & I & II & 1 & $\mathrm{P}$ & $\mathrm{M}$ & - & " \\
\hline 3 & 76 & $\mathrm{~F}$ & 0 & II & 2 & $\mathrm{R}$ & $\mathrm{S}$ & - & " \\
\hline 4 & 72 & $\mathrm{M}$ & 0 & IIlb & 1 & $\mathrm{R}$ & S & - & " \\
\hline 5 & 74 & $\mathrm{M}$ & $\mathrm{I}>\mathrm{II}$ & IIlb & 4 & $\mathrm{R}$ & S & - & " \\
\hline 6 & 52 & $\mathrm{M}$ & 0 & I & 1 & $\mathrm{P}$ & S & - & " \\
\hline 7 & 83 & $\mathrm{~F}$ & 0 & I & 1 & $\mathrm{R}$ & $M$ & - & " \\
\hline 8 & 45 & $\mathrm{M}$ & $0>I$ & II & 1 & $\mathrm{P}$ & M & + & $" \prime$ \\
\hline 9 & 37 & F & 0 & I & 0.5 & $\mathrm{P}$ & $\mathrm{S}$ & + & " \\
\hline 10 & 72 & $\mathrm{M}$ & I $>$ II & $\mathrm{V}$ & 6 & $\mathrm{P}$ & $\mathrm{S}$ & + & $"$ \\
\hline 11 & 64 & $\mathrm{M}$ & I & $\mathrm{V}$ & 5 & $\mathrm{P}$ & M & + & " \\
\hline 12 & 78 & $\mathrm{M}$ & 1 & IIlb & 1 & $\mathrm{P}$ & $\mathrm{S}$ & - & $"$ \\
\hline 13 & 66 & $\mathrm{M}$ & 0 & $\mathrm{~V}$ & 1 & $\mathrm{R}$ & $\mathrm{S}$ & - & " \\
\hline 14 & 66 & $\mathrm{M}$ & I & $\mathrm{V}$ & 1 & $\mathrm{R}$ & $\mathrm{M}$ & - & " \\
\hline 15 & 65 & $\mathrm{M}$ & I & II & 5 & $\mathrm{P}$ & $\mathrm{S}$ & - & $"$ \\
\hline 16 & 59 & $\mathrm{M}$ & I & IIla & 0.5 & $\mathrm{R}$ & $\mathrm{S}$ & - & $"$ \\
\hline 17 & 69 & $\mathrm{M}$ & I & Illb & 0.5 & $\mathrm{R}$ & $\mathrm{S}$ & - & $"$ \\
\hline 18 & 48 & $\mathrm{M}$ & 1 & I & 4 & $\mathrm{R}$ & $\mathrm{S}$ & - & $"$ \\
\hline 19 & 49 & $\mathrm{M}$ & 1 & IIla & 4 & $\mathrm{R}$ & $\mathrm{S}$ & - & " \\
\hline 20 & 80 & $\mathrm{M}$ & I & Illa & 7 & $\mathrm{R}$ & $\mathrm{M}$ & + & $"$ \\
\hline
\end{tabular}

材料の採取法別にみると，自排尿は15例で計34回採 取し， 4 例の計 4 回 $(11.8 \%)$ に分裂中期細胞を計 14 個, 1 回平均3.3個認めた. pumping は14例で計16回採 取し，12例の計12回（75\%）に，分裂中期細胞を計 94 個, 1 回平均7.8個認めた。すなわち pumping の成功 率は自排尿よりも有意に高く $(\mathrm{p}<0.001)$ ，かつ得られ た分裂中期の細胞数も多い傾向にあつた $(\mathrm{p}<0.25)$.

な扮材料の採取回数は 1 例につき 1 回ないし数回平 均 2.5 回であるが, 全体の半数の 10 例では 1 回しか採取 しなかつた。 1 回のみ採取した 10 例中，自排尿の 5 例 中 2 例に対し pumping では 5 例中 5 例に分裂中期細 胞を認めており,やはり pumping の方の成功率が有意 に高かつた $(\mathrm{p}<0.05)$.

(b) Mitotic index: Table 6 に示したごとく0.5か ら 5 末でで平均 $2.40 \pm 0.46$ となり，これは対照に比べ て有意に高値であつた $(\mathrm{p}<0.005)$.

剝離細胞の M. I. を腫瘍の組織学的 grade, 初発か再 発か，単発か多発か，又腫瘍の大ささ等の面から検討
してみた。

grade I 以上の群の M. I. は平均 $3.08 \pm 0.2$ に対し, grade 0 では平均 $1.07 \pm 0.17$ と有意に差が認められた $(\mathrm{p}<0.025)$. 初発性腫瘍と再発性腫瘍を比べると前者 は平均 $2.15 \pm 0.67$, 後者は平均 $2.30 \pm 0.50$ で有意差を 認めず，また単発性腫瘍（平均 $2.30 \pm 0.50$ ）と多発性

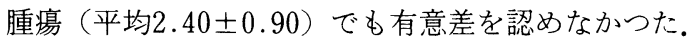

腫場の大ささをみる目安として膀胱造影での陰影欠 損の有無で分けると, 陰影欠損を認めるものでは平均 $3.42 \pm 1.09$, 認めないものでは平均 $1.90 \pm 0.41$ と前者 の方が高值であるが有意の差はなかつた $(\mathrm{p}<0.10)$.

なお染色体分析可能な分裂中期細胞は認められなか つたが M.I. は高值を示す例もあつた，症例〔No. 20〕 は再発性の多発性表在性乳頭状腫瘍で組織学的には grade I であつたが， M. I. は 7 と高值で分裂が盛んな 生物学的に悪性度の高い腫瘍である事が示唆された。 この症例は半年後に右下腹壁と左鎖骨下リンパ節への 腫愓転移を認めた。 
Table 3 Chromosome analysis (low stage bladder tumor patients)

\begin{tabular}{r|c|l|c|c}
\hline $\begin{array}{c}\text { Case } \\
\text { No. }\end{array}$ & Mode & Ploidy & $\begin{array}{c}\text { Range of } \\
\text { chromosome }\end{array}$ & $\begin{array}{c}\text { Total cells } \\
\text { counted }\end{array}$ \\
\hline 1 & 46 & diploid & $46 \sim 150$ & 5 \\
\hline 2 & 46 & diploid & $46 \sim 90$ & 6 \\
\hline 3 & 37 & neardiploid & $32 \sim 49$ & 25 \\
\hline 4 & $-*$ & - & $0 \sim 90$ & 4 \\
\hline 5 & - & - & $40 \sim 90$ & 3 \\
\hline 6 & - & - & $41 \sim 43$ & 2 \\
\hline 7 & - & - & $30 \sim 40$ & 3 \\
\hline 8 & 46 & neardiploid & $40 \sim 49$ & 8 \\
\hline 9 & - & - & 45 & 1 \\
\hline 10 & 71 & hypertriploid & $58 \sim 130$ & 15 \\
\hline 11 & - & neardiploid & $37 \sim 99$ & 13 \\
\hline 12 & - & - & $50 \sim 100$ & 3 \\
\hline 13 & 74 & neartriploid & $65 \sim 77$ & 9 \\
\hline 14 & 46 & neardiploid & $44 \sim 46$ & 10 \\
\hline$*$
\end{tabular}

$*$ : undetermined

(C) 染色体分析：結果は Table 3 に示した.

分裂中期細胞は 2 から 25 個， 1 例につき平均 7.6 個認 められたが， 5 個未満のものも約 $1 / 3$ あつた。

mode 抒よび ploidyを調べる事が出来たのは 8 例 (57.1\%)であるが，組織学的 grade 別にみると grade 0 の 7 例ではらち 2 例が 2 倍体附近に, 1 例が 3 倍体 附近に mode 拉よび ploidyをもつていた。 それ以外の 4 例は分裂中期細胞数が少なかつたため, modeや ploidy は判定不能であるが， 3 例は 2 倍体ないし 2 倍 体附近の細胞を認め, 残り 1 例は 4 倍体以上の細胞を 認めた.grade I 以上の 7 例では 4 例が 2 倍体又は 2 倍 体附近に mode 拉よび ploidyをもつが，1例を除いて 染色体数は分散して抢り，2 例に 4 倍体以上の細胞が, 1 例に低 4 倍体の細胞が認められた。 また 1 例は高 3 倍体に mode 拉よび ploidy をもつが染色体数が分散 しており, 半数が 4 倍体以上の細胞であり, かつ marker 染色体子認められた。 その他の 2 例では mode お よび ploidy は判定不能であるが，いずれも 4 倍体以上 の細胞が認められた。

(d) 尿細胞診：通常の細胞診は 20 例中半数の 10 例が 陽性（class V 6 例，IIIb 4 例）であつた. grade I 以 上のものの陽性率は $54 \%$ で, grade 0 の $28.5 \%$ より高 かつたが，有意差ではなかつた（ $\mathrm{p}<0.10 ）$.

以下代表例を示す。
〔No. 8〕は45歳男子，膀脱右側壁に小豆大から拇指 頭大の多発性の乳頭状有茎性腫瘍があり, TUR 施行. 組織学的には大部分は grade 0 であるが一部に (Fig. 1 -a）のごとき grade I もある移行上皮癌であつた。

膀胱鏡検查時に pumping 乙剝離細胞中に分裂中期 細胞を 8 個認めた。染色体数分布をみると mode は46 であり，ploidyは 2 倍体附近であつた（Fig. 1-b)。

（Fig. 1-c）に示した分裂中期核板は染色体数46本で核 型分析の結果, 明らかな異常染色体は認められなかつ た.

この症例は組織学的には grade I の部分も認められ るが，永離細胞の染色体分析の結果からは生物学的悪 性度は比較的低いものと考兄られる。

〔No. 10]は72歳男子，左尿管口外側上方に $1 \times 1 \mathrm{~cm}$ の単発性の乳頭状有茎性腫瘍があり, TUR 施行. 組織 学的には大部分 grade I の移行上皮癌で一部に Fig. 2 -a のごとき Grade II の部分があつた。

膀羘鏡検查時に pumping 乙剥離細胞中に分裂中期 細胞を15個認めた。染色体数分布をみると染色体数は かなり分散しているが, mode は71であり ploidy は高 3 倍体であつた（Fig. 2-b). Fig. 2-cに示した分裂中 期核板は染色体数 150 本であり, marker 染色体のほか 染色体の切断も認められた。

この症例は組織学的にも一部 grade II の部分があ り, 又染色体分析の結果から生物学的悪性度の比較的 高いものであると考兄られる。

〔No. 13〕は65歳男子，1978年に右尿管腫瘍（grade I, stage A）のために右腎尿管全摘除術が施行された. その後 3 回膀胼内腫瘍は再発し TUR が施行され，い ずれも組織学的には grade Iであつた。1981年10月膀 胱後壁に $5 \times 5 \mathrm{~mm}$ の単発性の乳頭状腫瘍が再発し, こ れは組織学的には grade 0 (乳頭腫)（Fig. 3-a）と診 断された。

この症例も膀胼鏡検查時に pumping し剝離細胞中 に分裂中期細胞を 9 個認めた。染色体数分布をみると mode は74で ploidy は高 3 倍体であつた (Fig. 3-b).

Fig. 3-c に示した分裂中期核板は染色体数74本であ るが，異常染色体の有無は不明である。

この症例は組織学的には grade 0 であるが染色体分 析の結果は良性乳頭腫よりも癌を思わせる。TUR後 も現在尿細胞診は class Vであり臨床経過からみて carcinoma in situ の存在も否定出来ないものと思う.

II. 浸潤性膀胼癌

各症例の臨床 data は Table 4 に示したが，いずれ 
Table 4 Clinical data (high stage bladder tumor patients)

\begin{tabular}{|c|c|c|c|c|c|c|}
\hline $\begin{array}{l}\text { Case } \\
\text { No. }\end{array}$ & Age & Sex & $\begin{array}{c}\text { Histology } \\
\text { (grade) }\end{array}$ & $\begin{array}{l}\text { Cytology } \\
\text { (class) }\end{array}$ & M.I. * & Treatment \\
\hline 21 & 67 & M & III & $\mathrm{V}$ & 12 & TUR-irradiation \\
\hline 22 & 66 & $\mathrm{~F}$ & III & $\mathrm{V}$ & 2 & Irradiation-cystectomy \\
\hline 23 & 54 & $\mathrm{M}$ & IV & $\mathrm{V}$ & 9 & " \\
\hline 24 & 68 & F & III & $\mathrm{V}$ & 2 & " \\
\hline 25 & 61 & $\mathrm{~F}$ & III & $\mathrm{V}$ & 8 & " \\
\hline 26 & 46 & $M$ & III & $\mathrm{V}$ & 15 & $"$ \\
\hline 27 & 64 & $\mathrm{~F}$ & III & $\mathrm{V}$ & 20 & $"$ \\
\hline 28 & 61 & $\mathrm{M}$ & III & $\mathrm{V}$ & 5 & $"$ \\
\hline 29 & 54 & $\mathrm{~F}$ & III & $\mathrm{V}$ & 6 & $"$ \\
\hline 30 & 64 & $M$ & II & IIIb & 5 & TUR-irradiation \\
\hline 31 & 69 & $M$ & III & $\mathrm{V}$ & 2 & TUR-irradiation \\
\hline 32 & 74 & $M$ & III & IIlb & 1 & TUR \\
\hline 33 & 60 & $\mathrm{~F}$ & SCC & IV & 0.5 & Part. cystectomy \\
\hline 34 & 40 & $M$ & SCC & $\mathrm{V}$ & 2 & Irradiation \\
\hline 35 & 78 & $M$ & III & $\mathrm{V}$ & 3 & TUR \\
\hline 36 & 59 & $M$ & III & $\mathrm{V}$ & 2 & TUR \\
\hline
\end{tabular}

*: mitotic index per 1000 cells

Table 5 Chromosome analysis (high stage bladder tumor patients)

\begin{tabular}{c|c|c|c|c}
\hline $\begin{array}{c}\text { Case } \\
\text { No. }\end{array}$ & Mode & Ploidy & $\begin{array}{l}\text { Range of } \\
\text { chromosome }\end{array}$ & $\begin{array}{c}\text { Total cells } \\
\text { counted }\end{array}$ \\
\hline 21 & $-*$ & - & $40 \sim 90$ & 4 \\
\hline 22 & - & nearpentaploid & $60 \sim 132$ & 6 \\
\hline 23 & 42 & neardiploid & $32 \sim 76$ & 35 \\
\hline 24 & - & - & 86 & 1 \\
\hline 25 & 50 & hyperdiploid & $35 \sim 115$ & 60 \\
\hline 26 & 105 & hypopentaploid & $58 \sim 112$ & 10 \\
\hline 27 & 130 & hypohexaploid & $87 \sim 157$ & 20 \\
\hline 28 & - & - & 104 & 1 \\
\hline 29 & - & - & 103 & 1 \\
\hline 30 & - & - & $30 \sim 40$ & 2 \\
\hline
\end{tabular}

*: undetermined

も乳頭状又は非乳頭状の high-stage の浸潤性癌であ ク，組織学的には grade II 又は III であつた。16例中 半数の 8 例は放射線照射後に膀胱全剔除術が施行さ れ，残りは膀羘保存的ないし姑息的に治療されたもの である．16例中15例は初発例で，また14例は膀胱造影 で陰影欠損を認めた。
剥離細胞の短期培養法を 4 例に試又 2 例に分裂中期 細胞を認めたが，期待した程の良い状態の染色体標本 は得られなかつた。 よつて以後の染色体分析はすべて 直接法を用いて行なつた。

(a) 分裂中期細胞の発見率：材料の採取方法扔よび 採取回数をみると自排尿は 16 例で計 41 回採取して，16 例の計16回 (39\%) に分裂中期細胞を計149個, 1 回平 均9.3個認めた。

pumping は 3 例で計 7 個採取して, 2 例の計 3 回 (43\%)に分裂中期細胞を計 30 個, 1 回平均 10 個認めた. すなわち low-stage 群の場合と異なり, 自排尿と pumping とで成功率も細胞数も有意差を認めなかつ た. 自排尿での成功率は low-stage 群よりも有意に高 $<(\mathrm{p}<0.01)$, 分裂中期細胞数も多い傾向にあつた. pumping でも成功率は高くならないが $(\mathrm{p}<0.10)$, 分裂中期細胞数は多い傾向にあつた。

材料の採取は 1 例につき平均 2.9 回であるが，lowstage 群の場合と同様に全体の半数では 1 回しか採取 しなかつた。いずれも 1 回の自排尿だけで分裂中期細 胞を認めたのは 2 例のみ (25\%) で, low-stage 群の場 合と同様に 1 回のみの採取では分裂中期細胞が認めら れない事の方が多かつた。一方症例によつては pump- 
Table 6 Mitotic index (control \& urothelial tumor patients)

\begin{tabular}{c|l|r|r|r}
\hline \multicolumn{2}{c|}{} & $\begin{array}{l}\text { No. of } \\
\text { Pat. }\end{array}$ & $\begin{array}{l}\text { Range of } \\
\text { M.I. }\end{array}$ & Mean M.I. \pm S.E. \\
\hline \multirow{4}{*}{ I } & control & 23 & $0 \sim 0.5$ & $0.07 \pm 0.10^{*}$ \\
\cline { 2 - 5 } & U.T.I. (+) & 10 & $0 \sim 0.5$ & $0.10 \pm 0.06$ \\
\cline { 2 - 5 } & U.T.I. (-) & 13 & $0 \sim 0.5$ & $0.04 \pm 0.03$
\end{tabular}$\quad(\mathrm{p}<0.25)$

Table 7 Mitotic index (before \& after irradiation)

\begin{tabular}{c|c|c|c}
\hline \multirow{2}{*}{$\begin{array}{c}\text { Case } \\
\text { No. }\end{array}$} & \multicolumn{2}{|c|}{ M.I. * } & $\begin{array}{c}\text { Residual } \\
\text { tumor }\end{array}$ \\
\cline { 2 - 4 } & before & after & + \\
\hline 23 & 9 & 3 & - \\
\hline 24 & 2 & 0 & - \\
\hline 25 & 8 & 0 & + \\
\hline 26 & 15 & 0 & - \\
\hline 27 & 20 & 1 & + \\
\hline
\end{tabular}

$*$ : mitotic index per 1000 cells

ing を施行しても壊死組織からの細胞のみで分裂細胞 は認められず，この傾向は特に扁平上皮癌の場合著明 であつた。

(b) Mitoti index : Table 6 に示したごとく0.5から 20 までで平均 $6.16 \pm 1.29$ となり，対照揖よび low stage 群に比べて有意に高かつた $(\mathrm{p}<0.005, \mathrm{p}<$ $0.01)$.

5 例で放射線照射前後の M. I. を比べる事が出来

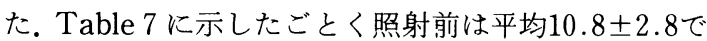
あつたが，照射後は平均 $0.8 \pm 0.5$ と有意の低下がみら れた $(\mathrm{p}<0.01)$. な打全摘膀胱に腫瘍が残存していた
2 例の照射後の M. I. はそれぞれ 3 と 0 で，残存腫瘍 のなかつた 3 例では 2 例が 0 で 1 例が 1 であつた。

症例〔No.27〕の放照線照射前後の剝離細胞の弱拡 大像を示すと，照射前 (Fig. 4-a) には分裂細胞がいく つか認められるが, 照射後 (Fig. 4-b) には変性した細 胞と扁平上皮細胞のみで分裂細胞は認められない。亦 た照射後の剝離細胞中には分裂中期細胞は全く認めら れなかつた。

(C) 染色体分析：結果は Table 5 に示した. 分裂中 期細胞は 1 から 60 個で 1 例につき平均 14 個認められ た。 5 個未満のものが半数あり, mode および ploidy を調べる事が出来たのは 5 例（50\%）である，4 倍体 以上の mode 拉よび ploidyをもつものが 3 例で, いず れも100本以上の染色体をもつ細胞が認められた。一方

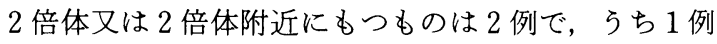
に 100 本以上の染色体をもつ細胞が, 他の 1 例に高 3 倍 体の細胞が認められた。

mode および ploidy を判定出来なかつた 5 例では, 1 例で低 2 倍体の細胞のみが認められたが，残り 4 例 ではすべて 4 倍体附近又は 4 倍体以上の細胞が認めら れた。

かつ10例中 4 例 (40\%) に marker 染色体が認められ た. 
Fig. 4 Urinary sediment cells of case 27 .

a Before irradiation, 3 dividing cells are indicated by arrow.

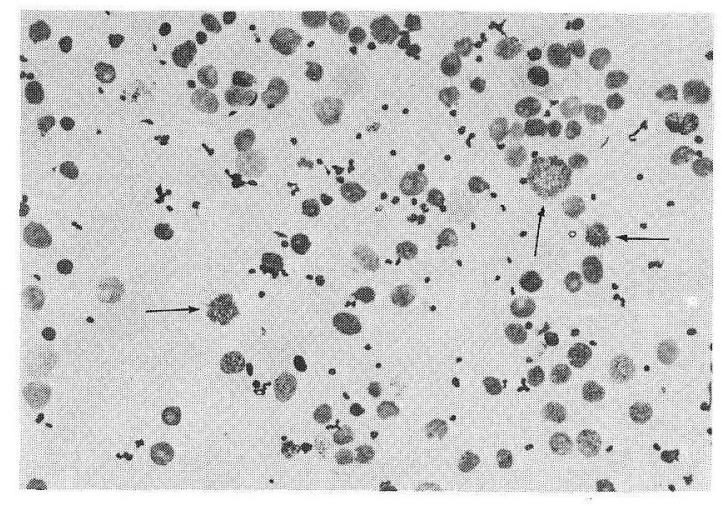

b After irradiation, ther is no dividing cell.

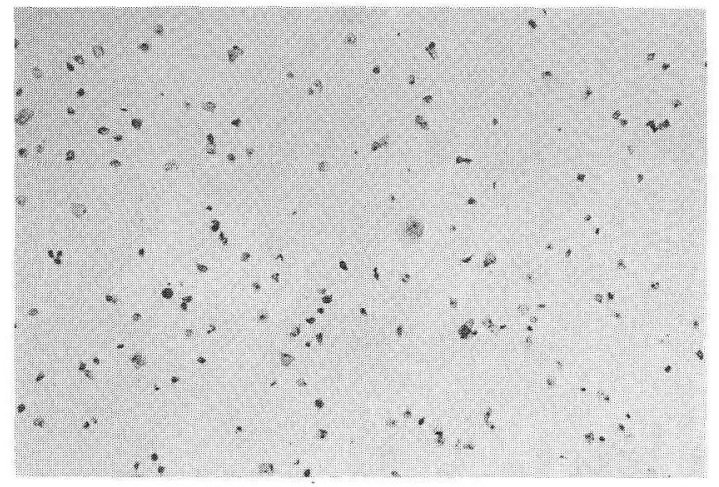

図はそれぞれ low-stage で grade 0 (Fig. 5-a), lowstage で grade I, II (Fig. 5-b) の乳頭状腫瘍，および high-stage, high-gradeの浸潤癌 (Fig. 5-c)，それぞ れの全ての分裂中期細胞の染色体数を表示したもので あるが， 2 倍体域の細胞は grade 0 の群でその割合が 最も多く, gradeが進むにつれて 2 倍体域の細胞の割 合は低くなる。また逆に grade, stage の高いもの程, 高 4 倍体以上の細胞の割合が多くなつていることが明 らかである。

(d) 尿細胞診：通常の尿細胞診は16例すべてが陽性 (class V13例, class IV 1 例, class IIIb 2 例)で, lowstage 群と比べて陽性率は有意汇高く $(\mathrm{p}<0.01)$ ，また class Vの占める割合も多い傾向が認められた。

以下代表例家す。

〔No. 23〕は54歳男子, 膀胼内びまん性広基性腫煬 があり，生検の結果 Fig. 6-a に示したごとき grade III
Table 8 Clinical data (ureteral \& renal pelvic tumor patients)

\begin{tabular}{c|c|c|c|c|l}
\hline $\begin{array}{c}\text { Case } \\
\text { No. }\end{array}$ & Age & Sex & $\begin{array}{c}\text { Cytology } \\
\text { (class) }\end{array}$ & M.I. * & \multicolumn{1}{c}{ Clinical diagnosis } \\
\hline 37 & 51 & M & Ila & 5.0 & Rt. renal pelvic tumor \\
\hline 38 & 66 & M & V & 0.5 & Rt. ureteral tumor \\
\hline 39 & 65 & M & V & 0.5 & Rt. ureteral tumor \\
\hline 40 & 50 & F & V & 0.5 & Lt. renal pelvic tumor \\
\hline
\end{tabular}

の移行上皮癌であり, 術前照射 $4,000 \mathrm{rad}$ 施行後1980年 12月17日膀胱全摘除術施行.

放照線照射前に自排尿を採取して，剝離細胞中に分 裂中期細胞を35個認めた。染色体数分布をみる mode は42で, ploidyは低 2 倍体であるが, 約10\%の細 胞が3倍体附近にあつた（Fig. 6-b）。

Fig. 6-c に示した分裂中期核板は染色体数65本で, 核型分析の結果 7 本の marker 染色体捛よび 3 本の䍩 小染色体と思われるものが認められた。

この症例は染色体分析の結果から ploidy が低 2 倍 体であるが, marker 染色体を認める細胞も方り, 生物 学的悪性度の高い腫瘍と思われる。

[No. 26〕は46歳男子, 他医でTUR を受け Fig. 7 -aのごとき grade III の移行上皮癌と診断され，当科 へ送られた。

術前照射 $4,000 \mathrm{rad}$ 施行後, 1981年 3 月 4 日膀胱全摘 除術施行。

放射線照射前の自排尿中には充分な剝離細胞が認め られなかつたために pumping して, 分裂中期細胞を10 個認めた。染色体数分布をみると mode ploidy は低 5 倍体であつた（Fig. 7-b).

Fig. 7-cに示した分裂中期核板は染色体数約 100 本 で, marker染色体も認められる。

この症例も染色体分析の結果加生物学的悪性度の 高い腫瘍であると思われる。

\section{B，腎盂尿管腫瘍}

各症例の臨木 data は Table 8 に示した。

腎孟腫瘍の 2 例には腎尿管摘除術が施行され，尿管 尰瘍の 2 例には姑息的に放射線照射が施行された。4 例中 3 例は自排尿を，1例は回腸導管尿を用いた。

虽離細胞の M. I. は0.5から 5 をでで平均 $1.63 \pm$ 0.95であり対照に比べて有意に高かつた（ $\mathrm{p}<0.005 ）$.

分裂中期細胞は 1 例のみに認められた。この症例 〔No.37〕は51歳男子で, 1977年に再発性膀腅腫瘍のた め,膀脱全摘除術および回腸導管造設術を施行された。 
Fig. 5 Summary of chromosome numbers in bladder tumor.

a Superficial pap. tumor (Grade 0)

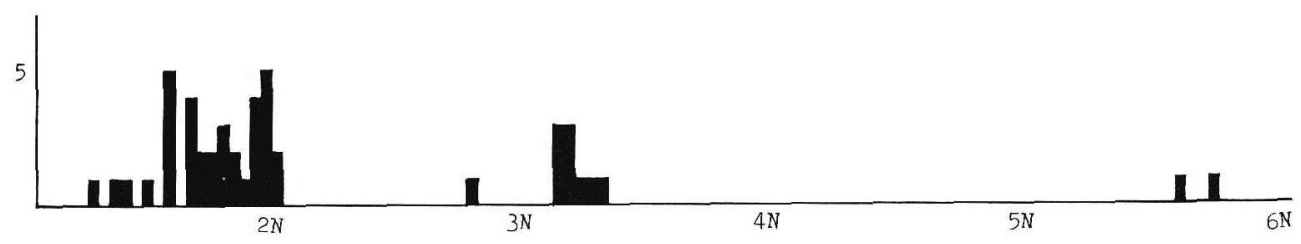

b Superficial pap. tumor (Grade I, II)

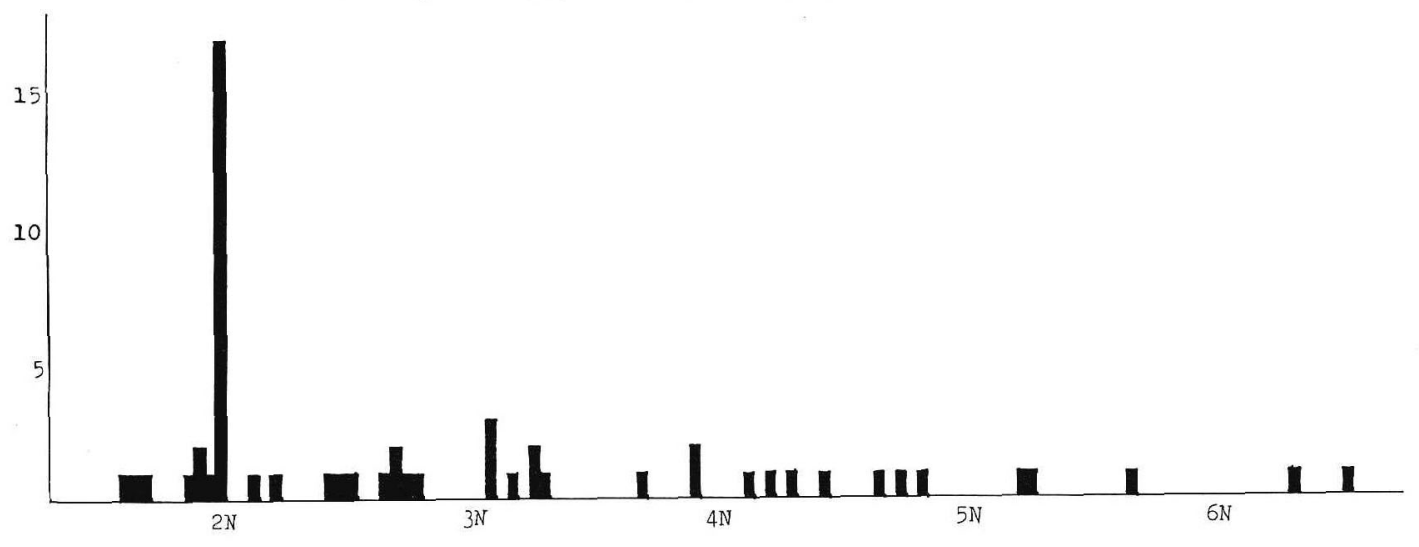

c Invasive ca. (Grade II, III)

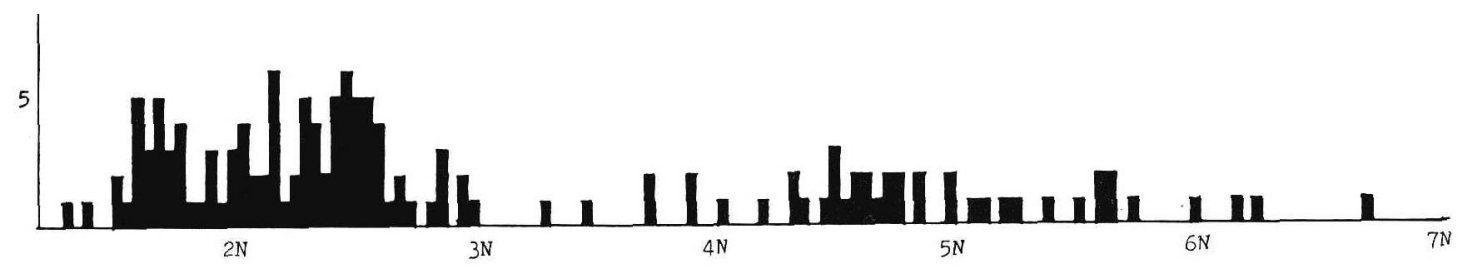

1980年 2 月に右腎結石のために腎血切石術が施行され

た、その後IVPKて右腎盂腎杯の院影欠損を認めた が，尿細胞診は陰性のために切石術の影響によるもの とも考皇たが, 腫瘍の疑いが強くなり1980年 7 月23日, 右腎摘除術施行, 組織学的に Fig. 8-a のごとき grade III の移行上皮癌であつた。

術前回腸導管尿の剝離細胞中に計 3 個の分裂中期細 胞が認められ，2 個は染色体数65，1 個注染色体数 100 であつた。

Fig. 8-b に示した分裂中期核板は染色体数65のもの で異常な大型の染色体も認められる。な和この症例で は手術時に採取した組織を用いて染色体分析した結 果, 染色体数の mode は65で, 剥離細胞中に認められ た分裂中期細胞が腫瘍細胞である事を裏付ける所見で
あつた。

考按

腫瘍細胞に多様な染色体異常が㕛られる事はよく知 られているが，このことが腫瘍の発生ないし増殖など にどの様な意義をもつかについては充分な結論は得ら 孔ていない.

腫瘍細胞の染色体を調べる目的は大別して2つあ る.第 1 の目的はある種の腫瘍について共通の染色体 異常を発見し, 腫洗の発生, 増殖, 転移等にどの染色 体，すなわち遺伝子が関与しているかを調べる事であ る. そのためには多数の症例について, 出来るだけ詳 細に分染法を用いて調べる必要がある。

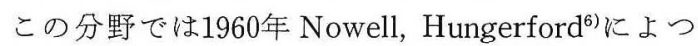
て，慢性骨髄性白血病（CML）に共通な染色体異常子 
Fig. 1 (Case 8)

a Histopathological appearance. Well differentiated transitional cell carcinoma (Grade $0>$ I).

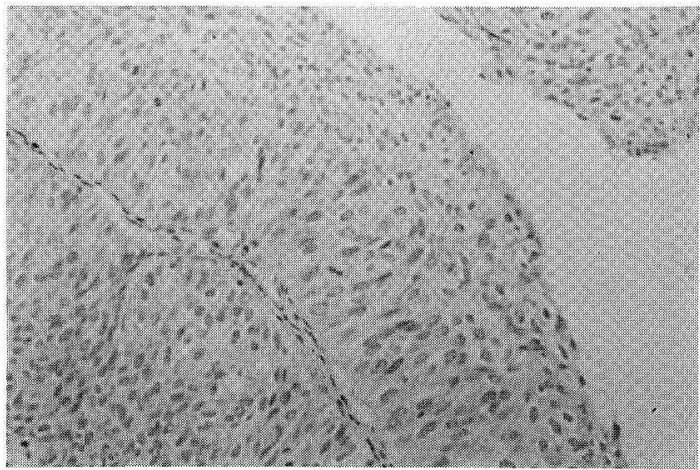

b Distribution of chromosome numbers. The modal number is 46 and the ploidy is neardiploid.

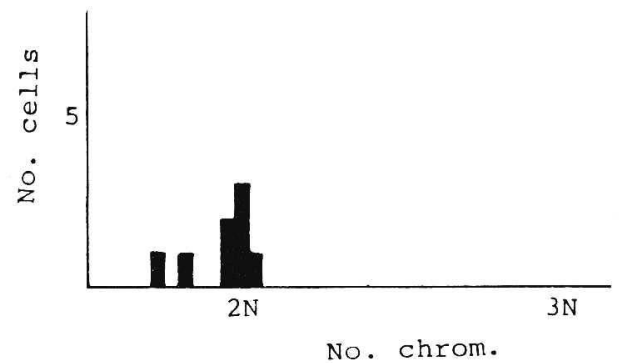

No. chrom. c Metaphase plate and karyotype. The chromosome number is 46 , abnormal chromosome is not apparant.
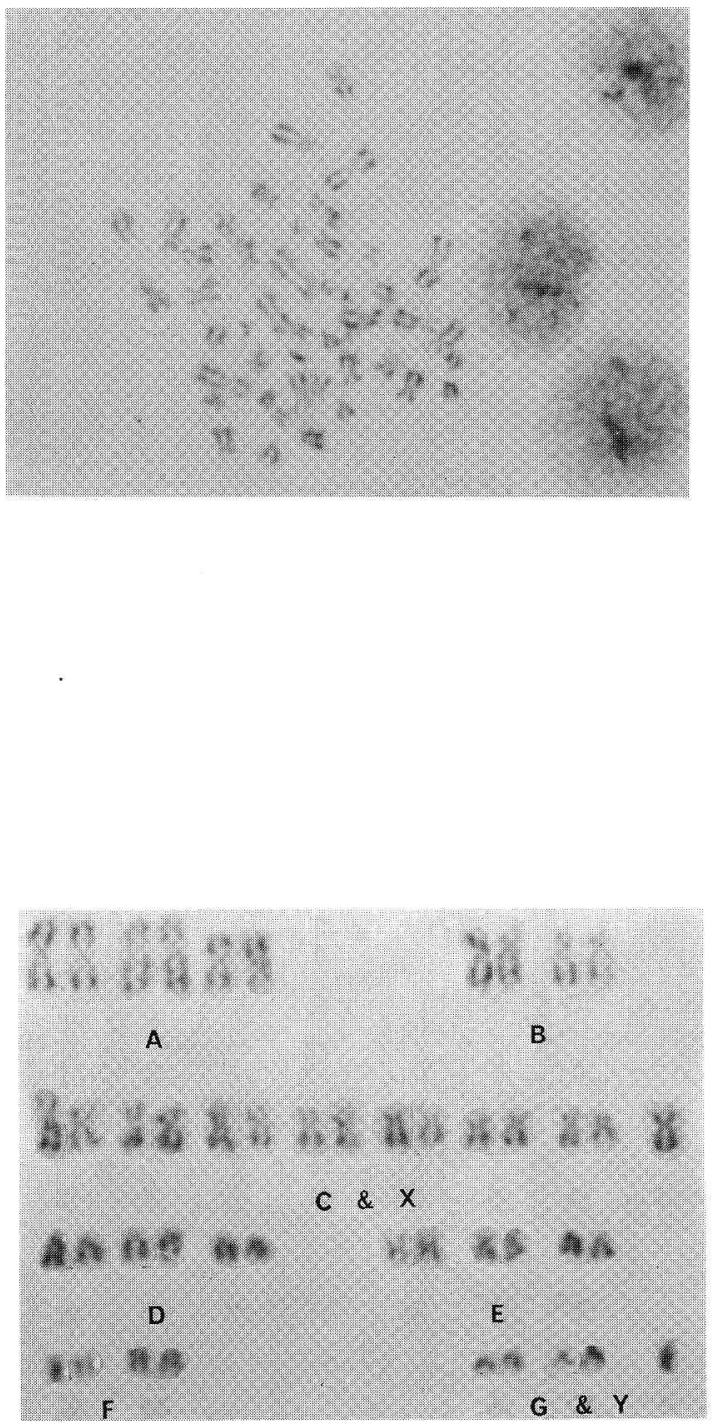
Fig. 2 (Case 10)

a Histopathological appearance. Moderately differentiated transitional cell carcinoma (Grade I $>$ II).

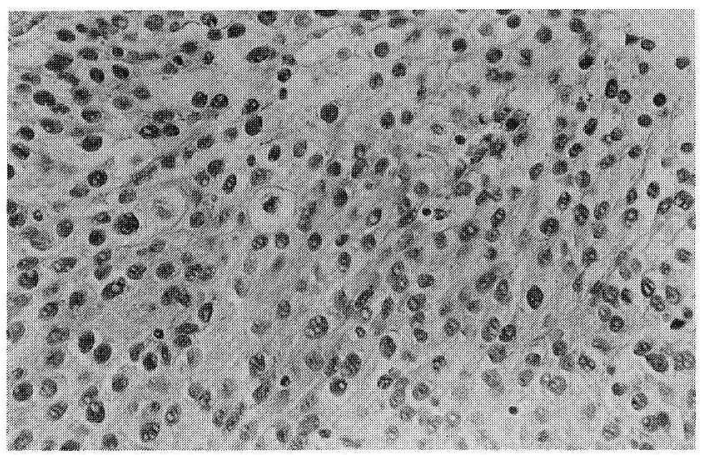

b Distribution of chromosome numbers. The modal number is 71 and the ploidy is hypertriploid.

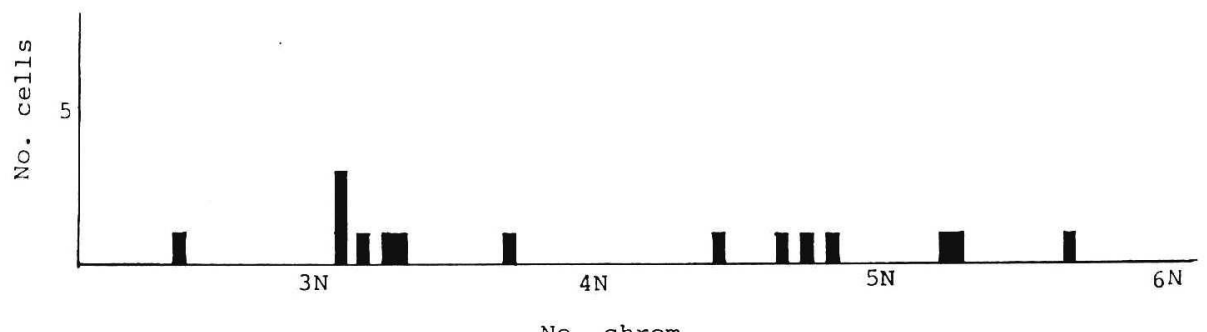

No. chrom.

c Metaphase plate. The chromosome number is over 100 , marker chromosome (M) and breakage (B) are indicated by arrow.

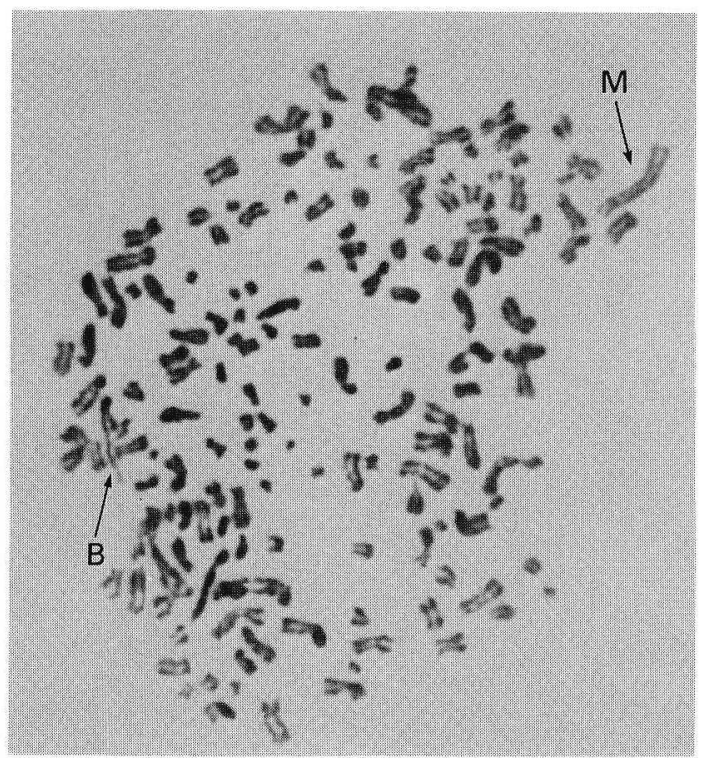


Fig. 3 (Case 13)

a Histopathological appearance. Well differentiated transitional cell carcinoma (Gade $0)$.

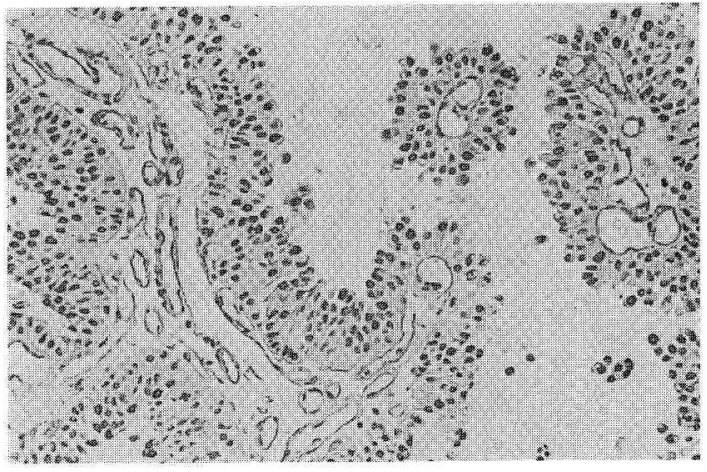

b Distribution of chromosome numbers. The modal number is 46 and the ploidy is neardiploid.

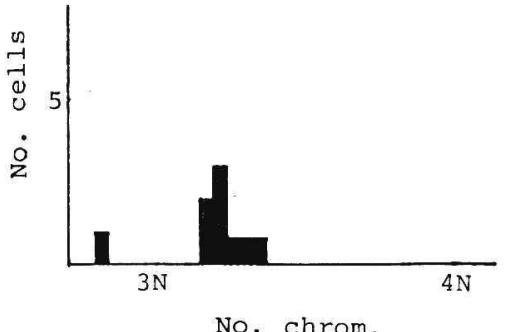

c Metaphase plate. The chromosome number is 74, abnormal chromosome is not apparant.

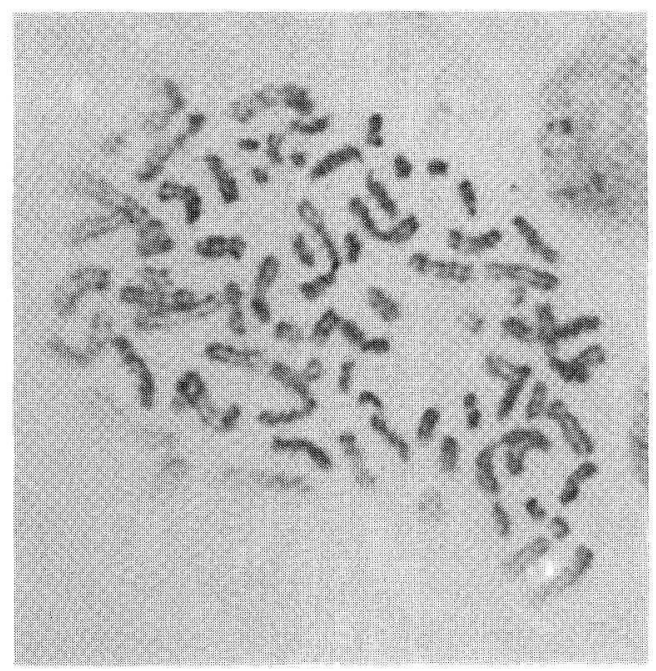


Fig. 6 (Case 23)

a Histopathological appearance. Poorly differentiated transitional cell carcinoma (Grade III).

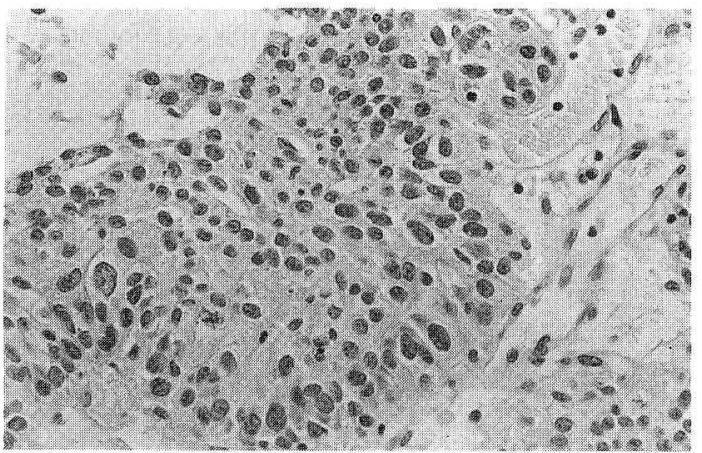

b Distribution of chromosome numbers. The modal number is 42 and the ploidy is hypodiploid.

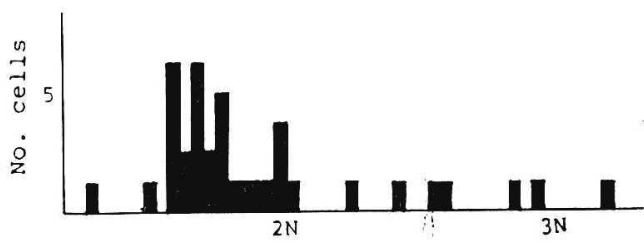

No. chrom. c Metaphase plate and karyotype. The chromosome number is 65,7 marker chromosome (M) and 3 possible double minutes (?) are present.
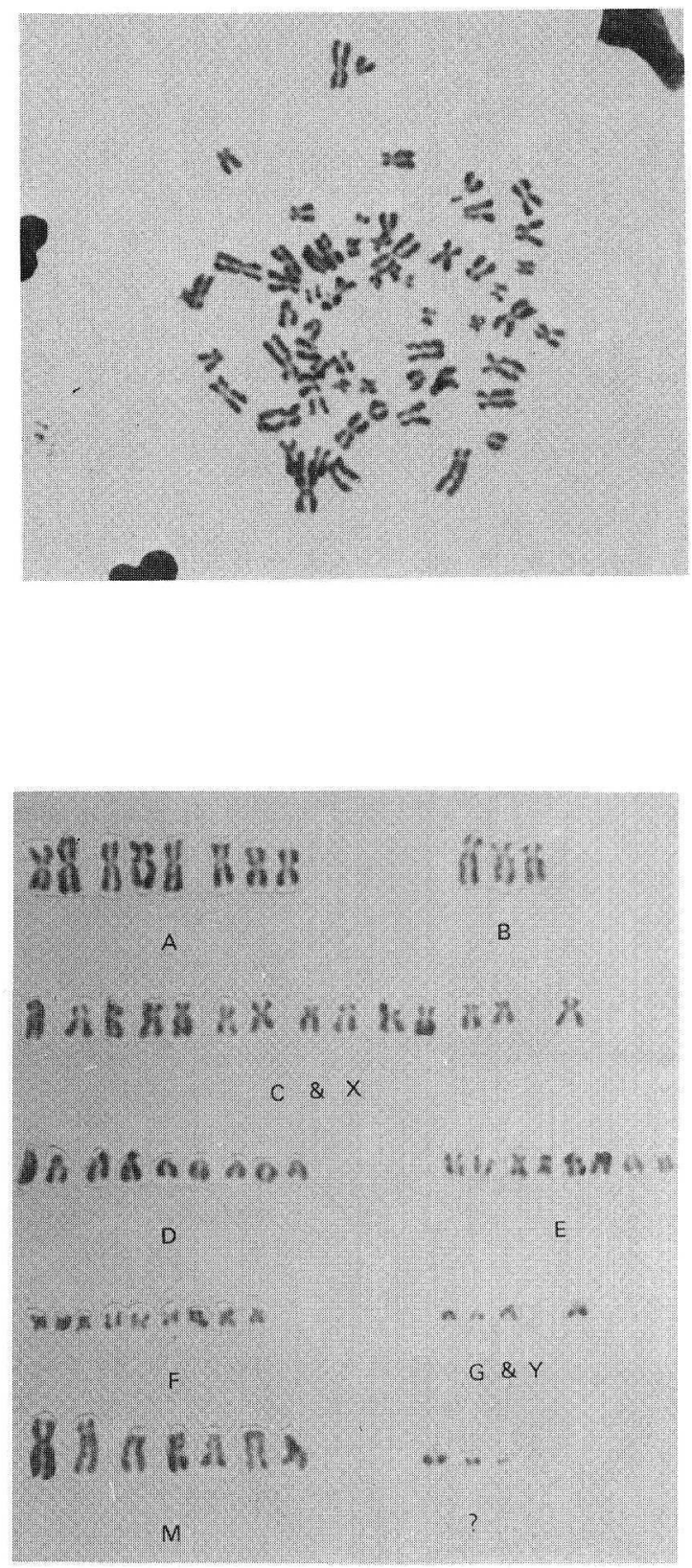
Fig. 7 (Case 26)

a Histopathological appearance. Poorly differentiated transitional cell carcinoma (Grade III)

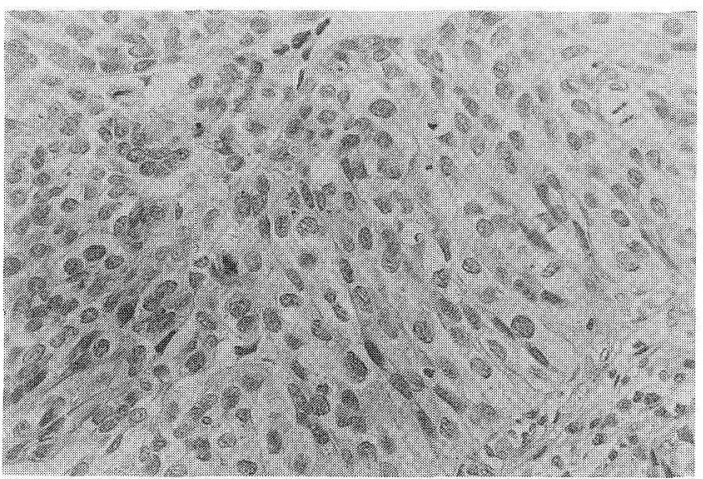

b Distribution of chromosome numbers. The modal number is 105 and the ploidy is hypopentaploid.

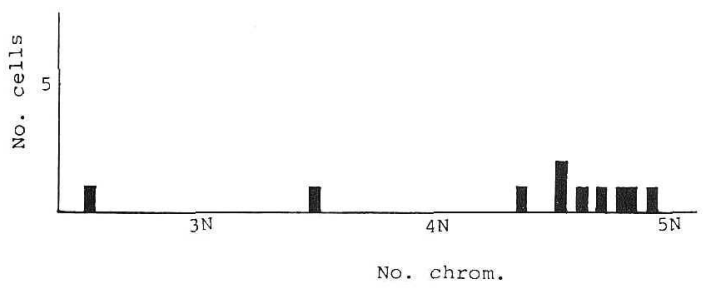

c Metaphse plate. The chromosome number is over 100, marker chromosome (M) is indicated by arrow.

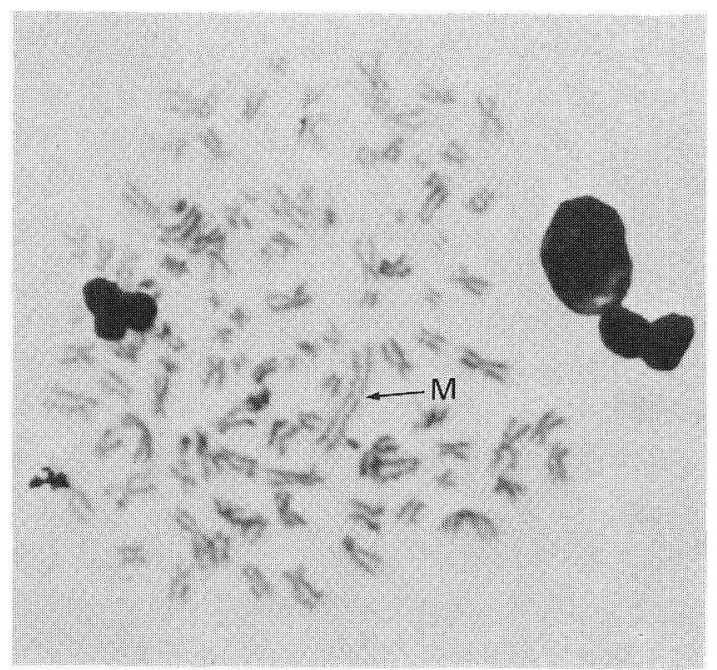

Fig. 8 (Case 37)

a Histopathological appearance. Poorly differentiated transitional cell carcinoma (Grade III)

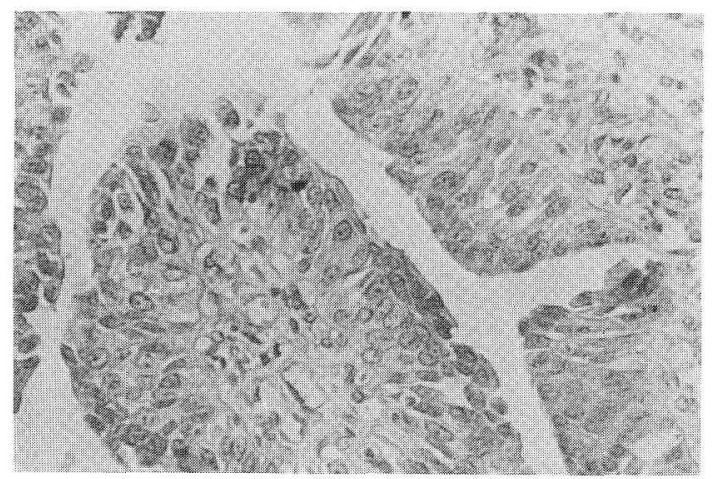

b Metaphase plate. The chromosome number is 65, large abnormal (possible marker) chromosome is indicated by arrow.

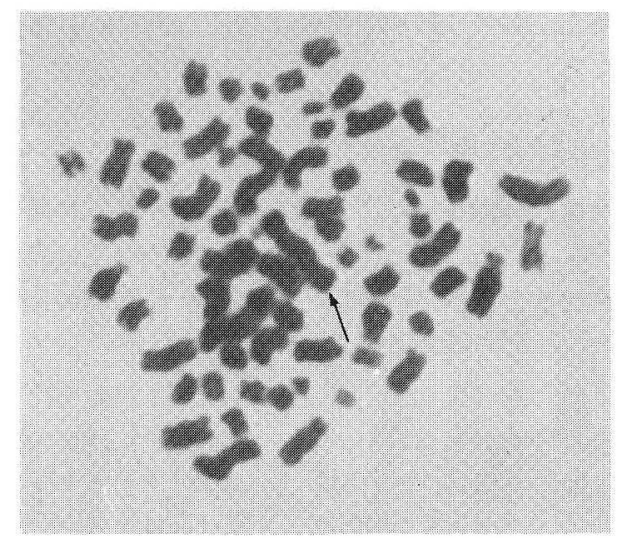


して発見された $\mathrm{Ph}^{\prime}$ 染色体がよく知られており，これ は当初No. 21染色体の長腕欠失と考光られていたが, 1970年代に入つて分染法の発達により, No. 9 と No. 22の両染色体長腕間の転座であることが発見され (Rowly ${ }^{17)}$, 1973), CML の診断, 治療・予後の判定に 大いに役立つている。他の血液疾患でも様々な特異的 な染色体異常が報告されているが，腫瘍全体からみれ ばこれら血液疾患の場合はむしろ例外的である。固形 腫瘍では Meningioma でNo. 22染色体の異常が認め られる8)他に，二，三の腫瘍に関する報告も散見される が，尿路腫瘍をはじめとして大部分のヒトの固形腫瘍 ではその腫瘍に特有の染色異常は認められていない。 その理由として，固形腫瘍の染色体分析が血液や骨髄 を用いた場合に比べて技術的に難しいということの他 に，材料を入手しにくいということもあげられる.

固形腫瘍では原発巣を手術的に切除又は生検したも のを用いる他に，しばしば転移巣や腹水・胸水などが 用いられ，この様な場合当然腫瘍はかなり進行した状 態であり，2 次的な複雑な染色体異常を伴つている場 合が多く，かりに初期段階では共通の染色体異常が存 在したとしても隠されてしまう可能性がある ${ }^{9)}$. また 原発巣を材料としても診断が困難な部位のものは初期 癌でない場合が多い。

この点, 膀脂腫瘍は内視鏡的操作で容易に初期の腫 瘍を採取することが出来るので, 共通の染色体異常が 発見される可能性は他の部の腫瘍よりも高いかも知れ ない.

第 2 の目的は染色体分析が腫瘍の生物学的悪性度を 判定する一助とならないかといらことで, 腫瘍の早期 診断, 臨床経過拉よび予後の判定に役立てよらとする わけである。

現在尿路腫瘍の染色体検査は主として第 2 の目的で

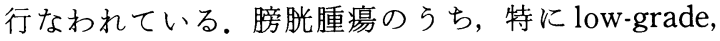
low-stage の乳頭状腫瘍は一般に多中心性発生傾向が 強いため個々の腫瘍をTUR で完全に切除しても高率 に頻回再発を来たし，その一部は多年月の経過中に high-grade の浸潤癌となることが知られている.

この意味で光䫓レベルでは同一にみえる low-grade の膀胖腫場の生物学的悪性度を予測する方法の開発が 強く要望されている. その方法としては現在の所, $\mathrm{ABH}$ 同種抗原検索, 電顕による微細構造の観察, 核 DNA の定量等の方法があり, 染色体分析もその一つ である。

しかし初期の小さな膀胼腫瘍の場合は手術的に採取
した材料でも染色体分析を行うのに充分な量でない場 合がある，又肉眼的に腫瘍の存在がはつきりしない carcinoma in situ (CIS) や silent tumor ${ }^{10)}$ の場合も ある。こうした場合に剝離した腫瘍細胞を用いれば, 材料は容易にかつ何度でも手に入れる事が可能であ る.

我々は手術的に採取した腫瘍組織は主として前述の 第 1 の目的に用いることとし，技術的には難しいが良 好な染色体の得られる短時間の組織培養を行なつて詳 細な染色体分析を行なつている。

一方剝離細胞を用いる場合には無菌的操作が比較的 難しいために，我々は直接法を主に用いている，直接 法は技術的には比較的容易である反面分裂細胞が充分 でない場合があり, かつ得られた染色体も短期培養法 に比べて条件がよくないことが多く，したがつて詳細 な染色体分析には余り適していない。ただし直接法は 腫湯組織を用いた染色体分析が成功しなかつた場合の 補助として有用であり, また術前診断や経過観察の場 合通常の尿細胞診の補助としての意義もある.

(1) ヒ上尿路上皮の細胞回転

従来腫瘍以外のヒトの尿中剝離細胞を細胞遺伝学的 立場で本格的に調べたものは見当らない様である，正 常のヒトの尿中の剥離細胞中にどの位の頻度で分裂細 胞が含まれる可能性があるのか，この点についてまず ヒトの尿路上皮の細胞回転を知る必要がある.

文献的にみると, Pringle ら ${ }^{11)}$ が, 正常のヒト膀胱粘 膜で分裂細胞の認められる頻度は約 $0.01 \%$ であると報 告しており, Hainau 5 ${ }^{12)}$ は, ${ }^{3} \mathrm{H}$-Thymidine $の$ 細胞内 の取込みよりみて正常の膀胱粘膜の分裂頻度は $0.12 \%$ で，細胞回転は520日であるとしている。

ヒト以外の哺乳類については, Clayson ${ }^{13)}$, Pringle ${ }^{11)}, \mathrm{Levi}^{14}{ }^{14}$ 等がマウス膀脱の分裂細胞は $0.1 \%$ 位の頻度で, DNAの合成も遅く尿路上皮細胞の平均 寿命は50〜200日位としている. Sharief ら ${ }^{15)}$ はイヌ， ブタ，ヒヒについて分裂細胞の頻度はいずれも約 $0.01 \%$ であると報告している。すなわちヒトを含めて 哺乳類では正常の尿路上皮の分裂細胞の割合はかなり 低く，したがつて剝離細胞中にも分裂細胞が認められ る可能性は極めて少ないものと思われる。

な敃炎症や外傷の場合は組織修復のために細胞分裂 が盛んになるといわれているが, Pringle ら $^{11}$ は炎症 下の膀胱粘膜で分裂細胞の頻度は約 $0.08 \%$ であると し, Hainau ら ${ }^{12)}$ も炎症のある組織とない組織での ${ }^{3} \mathrm{H}$ Thymidine の取り込みに差はみられなかつたとして 
招り，今回の我々の検討でも尿路感染の有無によつて 剝離細胞中の分裂細胞の頻度に差を認めなかつた。た だし我々の急性炎症例は 2 例のみであり，今後さらに 症例を増やすとともに剥離細胞のみでなく，炎症組織 自体を採取して検討を加える必要がある。

(2) 尿路腫瘍剝離細胞の Mitotic index

Pringle ら ${ }^{11}$ は尿路腫瘍に打ける分裂細胞の頻度は 約 $0.2 \%$ で, 正常の膀脱粘膜の約 20 倍であるとしてい る. Fulken $5^{16)}$ とよると分化型, 低分化型, 未分化型 の膀胼腫瘍の分裂細胞の頻度はそれぞれ，0.13\%， $0.48 \%, 1.31 \%$ で組織学的悪性度と相関していたとい 5 .

Hainau ら ${ }^{12)}$ 膀胱腫瘍の ${ }^{3} \mathrm{H}$-Thymidine の取り込 久は組織学的 grade に一致して増加し, 特に腫瘍表層 で取り込みが強いことを報告している。

剥離細胞の M. I. が実際の尿路腫瘍の分裂状態をど の程度反映しているかについては更に今後の検討を要 するが，今回の我々の研究によると腫瘍の場合は非腫 瘍対照群に比べて有意に M. I. が高く，また同じ膀胱 腫瘍の中でも組織学的 grade とある程度相関して M. I. が高くなつている結果がえられて抢り, 剝離細胞の M. I. が腫瘍の生物学的悪性度の 1 つのメルクマール となる事が示唆された.Veenema ${ }^{17)}$ は組織学的に分化 型の膀脱腫瘍でも約 2 割は高い DNA 合成能を示すも のがありこの場合予後不良であるという，今回の我々 の検討でも組織学的に low-grade でも M. I. が高かつ た 1 例の予後が不良であつたことは注目されてよかろ 5 .

また放射線照射後に有意に M. I. の低下をみたこと は, 剶離細胞の M. I. 算定が放射線療法の効果判定の 一手段となる可能性をも示唆している.

(3) 剶離細胞中の分裂中期細胞

前述のごとく腫瘍以外の疾患では尿路上皮の細胞回 転が遅く，剝離細胞中の分裂細胞の頻度も極めて低い ために，染色体分析の可能な分裂中期細胞を認め万確 率も極めて低い. 腫瘍の場合は分裂頻度は low-grade のものでも正常の尿路上皮に比べて $10 \sim 20$ 倍高く, 当 然剝離細胞中に染色体分析が可能な分裂中期細胞を認 める確率も高くなるはずである。

逆に言学ば剝離細胞中に分裂中期細胞を認める場合 には, 細胞の分裂頻度が高い事を意味するわけである。 特に今回の検討で high-grade, high-stage の膀腅腫瘍 の方が low-grade, low-stage のそれょりも自排尿中 の剝離細胞で分裂中期細胞を認める頻度が高かつたこ
とは，悪性度が高い程腫瘍の分裂が盛んであることの 反映である。ただし余り分裂が盛んになると腫場の表 面が壊死に扮ちいりか兄つて分裂細胞を認めることが 少なくなる場合も当然あるわけで，この場合は剥離細 胞を用いる方法の限界となる。

な打正常の七トの尿路上皮から極く低い頻度ではあ るが分裂中の細胞が尿中に剥離する可能性も完全には 否定出来ないので, 次にヒトの正常尿路上皮細胞の ploidy について検討を加えてみる。

(4) ヒト正常尿路上皮の ploidy について

核DNA 量の測定によるヒト正常膀胼粘膜の ploidy に関する報告は文献上いくつかみられるが, 報 告者により意見が異なつている。

以前は Leuchtenberger $(1954)^{18)}$, Levi (1969) ${ }^{19)}$ ら により polyploidyであると報告されていたが，最近の Fossa $(1975)^{20)}$, Tribukait $(1978)^{21)}$, Jakobson $(1979)^{22)}$ ，星ら $(1980)^{23)}$ とよると大部分が 2 倍体であ つて 4 倍体以上の細胞は殆んど認められないとされて いる.

また, Sandberg (1977) ${ }^{24)}$ は75例のヒトの正常の膀 胱粘膜を短期培養法を用いて染色体分析し，90\%以上 の細胞が 2 倍体であるとし, 同時に52例の男子の正常 膀胱粘膜の Y-body がすべて 1 個のみであつたことも 2 倍体を裏づける所見としている。

星ら ${ }^{23}$ は膀胱炎例での尿中剝離細胞の核 DNA 量の 測定をし, 正常例に比べて分散傾向は強いが， 4 倍体 以上のものは殆んど出現しなかつたという，炎症例の 剝離細胞の染色体分析の報告は文献的にみあたらない ので比較出来ないが，我々の結果では分裂中期細胞は 全く認められなかつた。これは前述した様に炎症例で も分裂細胞の頻度が低い他に, 沈椬中に多核白血球, 細菌等が多数含まれているため，染色体分析を行なら には余り条件が良くないといらことも考えねばなら ず, したがつて炎症の場合の尿路上皮の ploidy を決定 するためには今後直接組織を採取して調べる必要があ る.

炎症の場合の ploidyは今の所はつきりした結論は 得られていないが，少なくとも正常の場合には殆んど 2 倍体で，かりに尿中剝離細胞の中に染色体分析可能 な分裂中期細胞が認められたとしてもとれは 2 倍体の はずである.

(5) 腫瘍の生物学的悪性度判定について

今回の我々の目的の 1 つは手術前の腫瘍染色体分析 により, 腫瘍の生物学的悪性度判定が可能か否かを検 
討することである。そのためには手術的手段によらな い剥離細胞を用いる方法が適して掞り，しかもこの方 法は何度も反映して出来る利点がある.特に pumping 等の機械的操作を用いない自排尿中の剝離細胞を用い て染色体分析が出来れば最適である。

しかし low-grade, low-stage の膀胱腫瘍の場合は 分裂が余り盛んでないことや，腫瘍表面から腫瘍細胞 の膀胱程度が high-grade, high-stage のものに比べて 弱い25) と等の理由から自然に利離した細胞中には充 分な分裂中期細胞を認めない場合が多い，その場合に は pumpingを施行し充分な数の分裂細胞を集めるこ とが必要であるが，この場合でもなるべく検査回数を 減らすために, 我々は原則として膀胼鏡検査施行時に 同時に行なら様にしている（膀胱鏡の sheath は Nelaton catheterより内径が大きいのでより効率的 に剥離細胞が得られる).

表在性の膀胱乳頭状腫瘍のらち grade 0 の 7 例中 5 例は 2 倍体および 2 倍体附近の細胞のみが認められた が， 3 倍体附近および 4 倍体以上の異数性の細胞が認 められたものも各 1 例ずつあつた。この結果は, 膀胱 腫瘍は 2 倍体として発生するといら説 ${ }^{19}$ や low-grade のものには 2 倍体のものが多いといら報告2)26) 301 に一 致するとともに, 組織学的診断々生物学的悪性度々が 必ずしも平行しない可能性をも示唆している. Greene

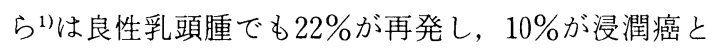
なると報告しており, 今回の我々の結果で grade $0 て ゙$ 異数性の細胞を有するものの臨床経過を今後注目して 追求したい。

grade I 以上の low-stage の膀胼乳頭状腫瘍では 7 例中 1 例では 2 倍体附近の細胞のみが認められたが, 残りの 6 例はすべて 4 倍体又は 4 倍体附近の異数性の 細胞を認め, 染色体数の分散が大きいものや中には marker 染色体を認めるものもあり, 大部分のものは 明らかに生物学的により悪性のものと考学られる。 Falor ら ${ }^{31)}$ 33) は腫瘍の生物学的悪性度の指標として は marker 染色体の有無が重要で, marker 染色体が 認められたものは浸潤傾向が強いとしている。したが つて術前に剥離細胞の染色体分析で marker 染色体が 認められたものは, 組織学的には low-grade であつて も特に充分な経過観察が必要である。

high-grade, high-stage の浸潤性膀胼腫瘍例では組 織学的悪性度と生物学的悪性度が比較的良く一致して おり，また腫瘍が大きく手術時に比較的多くの材料を 入手し易いこともあつて, 詳細な染色体分析の報告も
多い. Sandberg ${ }^{24)}$ は浸潤癌では染色体数の増加と marker 染色体を伴うことが多いと報告して扔り, 又 $\mathrm{Lamb}^{2)}$, Spooner ${ }^{34)} ら$ 同様の結果を報告している. 今回の我々の剝離細胞を用いた high-stage 例もこれ らと同様の成績であり，2 倍体又は 2 倍体附近の細胞 も認められるがその割合は low-stage のものに比べて 著しく低く, 10例中 9 例に 4 倍体以上の異数性の細胞 を認め, 約半数に marker 染色体を認めた。な抒 highstage 例では染色体数の分散が大きい場合にはより生 物学的悪性度が高いとする佐々木 ${ }^{26)}$ の報告に一致する と思われた. 要するに high-stage 例の場合は以上のご とく剥離細胞を用いた染色体分析でも明らかな異常を 認めることが容易であつた。

6) 尿細胞診と関連性

通常の尿細胞診の欠点として, 標本作製までに比較 的時間がかかること, 判定が必ずしも客観的でないこ と, 腫瘍の組織学的 grade と必ずしも相関しないこ $と^{35) 36)}$, 打よび特に尿路疾患では false positive の頻度 が高いこと(文献的には $2 \sim 6 \%{ }^{37}, 4.3 \%{ }^{38}, 5.7 \%{ }^{399}$, $\left.8.2 \%{ }^{40)}\right)$ などがあげられている.

これらの久点を剝離細胞の染色体検査で補うことが 出来ないが，すなわち数的にも形態的にも正常細胞と は異なる染色体を認める場合には細胞診の補正補助と して役立つ411のではなかろらかといらことが当然考克 られる。

ただ染色体異常を有する細胞がどの位の頻度で認め られれば腫瘍と診断するかという具体的な報告は，尿 路腫瘍の場合にはみあたらない。

Dewald $5^{42}$ は胸水中の腫瘍細胞の染色体を直接法 を用いて検索して通常の細胞診との比較を行なつてい る. 彼らの診断基準は少なくとも30個の分裂中期細胞 を観察して，その中に 2 倍体より数の多い異数性の染 色体をもつ細胞，あるいは marker 染色体をもつ細胞 が少なくとも 3 個以上認められた場合には腫瘍性の胸 水であるとしている.

彼らのによると正診断率は染色体分析で $71 \%$, 通常 の細胞診で $68 \%$ ，両者を組み合わせると $83 \%$ となり， 染色体分析を用いた診断法が通常の細胞診の補助とし て役立つことを強調している。

またHansson ら ${ }^{43)}$ もやはり直接法で胸水の染色体 分析を行ない, 通常の細胞診陰性で染色体分析により 腫瘍と診断出来た 1 例を記載し，この方法の利点とし て材料採取から標本が出来るまで比較的短時間（約 3 時間)で，かつ false positive の全くないことをあげて 
いる。

腫瘍性胸水は以前から染色体分析の長い材料として 用いられておう，単に数的異常のみならず分染法によ る分析も行なわれていわゆる偽 2 倍体などの異常も発 見されており，これを直ちに尿路腫瘍の場合にあては めることは出来ない。

我々の検討では尿中の剝離細胞のなかに含まれてい る分裂細胞数は一般に不充分のことが多く, 染色体分 析可能な分裂中期細胞 1 例につき平均10個 (low-stage の膀胱乳頭状腫湯では平均 8 個)であり, Dewald ら ${ }^{42)}$ の診断基準である30個以上の分裂細胞を観察出来たの は 2 例（5\%）のみであつた。

なお Dewald ら ${ }^{42)}$ は 2 倍体より染色体数の少ないも のを癌の診断基準から除外しているが，腫瘍で染色体 数が減る場合があることも知られており, 膀胱腫瘍に ついても悪性度が高いにもかかわらず低 2 倍体の染色 体数をもつ細胞が認められたといら報告がある24334.

いずれにしても今後さらに症例を増やして尿路腫瘍 の場合の診断基準を作らなくてはならないわけであ る. 今の所, 2 倍体の細胞が剝離細胞中に認められた 場合, それが為 2 倍体であるか否かは区別出来ないが, 分頻頻度（M. I.）を調べてそれが高ければ腫瘍である 可能性が高い. 特に従来 low-grade の膀胱腫瘍の細胞 診は false positive が多いとされておりり年〜48)，この点 染色体検査が将来役立つ可能性が高いと思 5.4 倍体 以上の異数性の細胞が認められた場合や, marker 染 色体を認める場合には生物学的悪性度が高い腫瘍であ る可能性が高くこの意味ではある程度の“grade”の 判定も可能であると思ら。

high-stage 例では, 明らかに異常な染色体が認めら れる頻度が高いことや，さらに我々の症例〔No. 37〕 の様に回腸導管尿で通常の細胞診は陰性で剝離細胞に 明らかに異常な染色体を認めた経験などは注目してょ からら。

染色体分析は比較的短時間に簡単に出来るので screening test として用いることも可能である。我々 の方法では材料の採取から標本作製，そして写真撮影 まで行なつても半日あれば充分であり，その判定もな れれば比較的容易である。ただし今の所 false negative（剥離細胞中に全く染色体分析可能な分裂中期細 胞が認められない場合)もかなりある。この場合は M. I. の算定と共に，核 DNA 量の測定 ${ }^{23)}$ ，剝離した間期 細胞の Sex-chromatin の観察 ${ }^{49)}$, 剝離細胞の ABH 同 様抗原検索 ${ }^{50}$ 等の方法も今後の検討課題となろう。染
色体検査と併行して通常の尿細胞診が必要なことは言 らまでもない。

\section{結語}

1.40例の尿路腫瘍について剥離細胞を用いた Mitotic indexの算定と染色体分析を行つた.

2. 尿路腫瘍以外の対照疾患では M. I. は平均 $0.07 \pm 0.10$ 低值で，かつ豩離細胞中に染色体分析可 能な分裂中期細胞は認められなかつた。な打尿路感染 のあるものとないものの M. I. はそれぞれ，0.10士 0.06, $0.04 \pm 0.03$ であつたが, 推計学的に有意差では なかつた。

3. 表在性膀脱乳頭状腫瘍の M. I. は平均 $2.40 \pm$ $0.46 て ゙$, 対照に比べて有意に高く, grade 0 のの $(\mathrm{M}$.

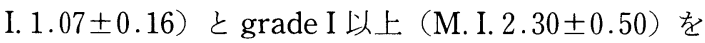
比べると, 後者の方が有意に高く，さらに high-grade, high-stage の浸潤癌では, 平均6.16士1.29の M. I. で あつた。すなわち剥離細胞の M. I. がある程度, 腫場 の分裂状態を反映している結果が得られた。

4. 分裂中期細胞は尿路腫瘍 40 例中 25 例 (62.5\%) 飞 認められた（膀胱腫瘍36例中24例，腎盂尿管腫瘍 4 例 中 1 例).

a ）表在性乳頭状腫瘍では20例中14例（70\%）に平 均7.6個の分裂中期細胞を認めた. grade 0 の 7 例では 5 例が 2 倍体附近の細胞のみを認め, 2 例で 3 倍体又 は 4 倍体以上の細胞を認めた.grade I 以上の 7 例では 2 倍体附近の細胞の及を認めたのは 1 例で, 残りの 6 例はすべて 4 倍体附近かそれ以上の細胞を認め，らち 1 例は marker 染色体をも認めた。

b ) high-grade, high-stage の膀胱浸潤癌では16例 中10例 $(62.5 \%)$ に平均 14 個の分裂中期細胞を認めた. 2 倍体附近の細胞のみを認めたのは 1 例で, 高 3 倍体 が 1 例， 4 倍体附近かそれ以上の細胞を認めたものが 8 例でうち 4 例に marker 染色体をも認めた。

腎孟尿管腫瘍で分裂中期細胞を認めたのは 4 例中 1 例（25\%）で，この 1 例は回腸導管尿の細胞診は陰性 であつたが，剥離細胞に異常染色体を 3 個認めたこと により確定診断がついた。

5. 材料の採取方法として, pumping 施行液の方が 自排尿やカテーテル尿よりも効率的に分裂中期細胞を 得られた.ただし high-stage の膀胼腫瘍では自排尿で 自然剥離した細胞中にも分裂中期細胞を認める率が高 く，中には自排尿の久で充分染色体分析可能なものも あつた。

6. 表在性膀胱乳頭状腫瘍では通常の尿細胞診が陰 
性でしかも剝離細胞中に分裂中期細胞が認められるも のがかなりあつた。ただし細胞診の補正補助診断とす るには今後さらに症例を増やして診断基準を決める必 要がある。

稿を終るにあたり, 御指導, 御校閲を賜つた恩師辻一郎教 授に深甚の謝意を表します。

また御指導, 御協力を載いた北海道大学理学部染色体研 究施設, 佐々木本道教授, ならびに阿部周一博士に深謝いた します。

本論文の要旨は第69回日本泌尿器科学会総会および第 5 5 回北海道癌談話会で発表した。

\section{文 献}

1) Greene, L.F., Hanash, K.L. and Farrow, G.M. : Benign papilloma or papillary carcinoma of the bladder. J. Urol., 110, 205-207, 1973.

2) Lamb, D.: Correlation of chromosome counts with histopathological appearance and prognosis in transitional-cell carcinoma of bladder. Brit. Med. J., 1, 273-277, 1067.

3）長山忠雄：剝離細胞による膀脂腫瘍染色体検索 法。医学のあゆみ，75，488-489，1970.

4）長山忠雄, 片海七郎：Pumping 法による膀脱腫瘍 の細胞診拉よび腫場細胞染色体の検索. 泌尿紀要, $18,5-11,1972$.

5）関根昭一：尿路ならびに男子性器腫瘍の染色体観 察。日泌尿会誌，67，452-464-1976.

6) Nowell, p.c. and Hungerford, D.A. : Chromosome studies on normal and leukemic human leukocyties. J. Nat. Cancer Inst., 25, 85-109, 1960.

7) Rowley, J.D.: A new consistent chromosomal abnormality in chronic myelogenous leukemia identified by quinarcine fluorescence and Giemsa staining. Nature, 243, 290-293, 1973.

8) Zankl, H. and Zang, K.D.: Cytological and cytogenetical studies on brain tumors. IV. Identification of missing $\mathrm{G}$ chromosome in human meningioma as No. 22 by fluorescenc technique. Humangenetik, 14, 167-169, 1972.

9）佐々木本道：染色体異常之癌発生，医学のあゆ久, 96, 312-315, 1976.

10）長山忠雄，片海七郎：いわゆる Silent Bladder Cancer について. 日泌尿会誌, 63, 427-437, 1972.

11) Pringle, J.A.S. and Williams, R.E. : Mitoses in human bladder biopsies. Annual Report, British Empire Cancer Campaign, 2, 237, 1967.

12) Hainau, B. and Dombernowsky, P.: Histology and cell proliferation in human bladder tumors. Cancer, 33, 115-126, 1974.

13) Clayson, D.B., Pringle, J.A.S., Bonsen, G.M. and
Wood, M.: The technique of bladder implantation further results and an assesment. Vrit. J. Cancer, 22, 825-832, 1968.

14) Levi, P.E., Cowan, D.L. and Cooper, E.H.: The induction of cell proliferation in the mouse bladder by 4 -ethylsulphonyl-naphtalene -1-sulphomide. Cell Tiss. Kinet., 2, 249-262, 1969.

15) Sharief, Y., Reich, III, C.F. and Vonar, R.A.: Polypolidy in mammalian urothelial cells. Urol. Res., 8, 153-161, 1980.

16) Fulken, M.J., Cooper, E.H. and Tanaka, T.: Proliferation an ultrastructure of papillary transitional cell carinoma of the human bladder. Cancer, 27, 71-82, 1970.

17) Veenema, R.J., Fingerhut, B. and Graff, S. : Nucleic acid synthesis in bladder tumors. Trans. Am. Assoc. Genitorium. Surg., 62, 155-159, 1970.

18) Leuchyenberger, C., Leuchtenberger, R. and Darris, A.M.: A microspectrophotometric study of the Deoxyribose Nuleic Acid (DNA) content in cells of normal and malignant human tissues. Amer. J Path., 30, 65-85, 1954.

19) Levi, P.E., Cooper,E.H., Anderson, C.K. and Williams, R.E.: Analysis of DNA content, Nuclear size and cell proliferation of transitional cell carcinoma in man. Cancer, 23, 1074-1085, 1969.

20) Fossa, S.D.: Feulgen-DNA-values in transitional cell carcinoma of th human bladder. Beitr. Path. Bd., 155, 44-55, 1975.

21) Tribukait, B. and Esposti, P.L.: Quantatative flow-microfluorometric analysis of the DNA in cells from neoplasms of th urinary bladder: Correration of aneuploidy with histological grading and th cytological findings. Urol. Res., 6, 201-205, 1978.

22) Jakobson, A., Bickel,P. and Sell, A.: Flowcytometric investigations of human blader carcinoma compared to histlogical classification Urol. Res., 7, 109-112, 1979.

23）星 宣次, 折 精一：核 DNA 含量測定の膀胱癌 及び尿細胞診への応用. 日泌尿会誌, 71, 458-467, 1980.

24) Sandberg,A.A.: Chromosome markers and progression in bladder cancer. Cancer Res., 37, 2950-2956, 1977.

25）布勢裕軸, 藤枝順一郎, 大室 博, 勝目三千人：膀 脂移行上皮癌の組織的電顕的研究 I. 腫瘍細胞の構 造と分化度. 日泌尿会誌，64，808-828，1973.

26）佐々木紘一：膀胼癌の染色体に関する研究一特に 予後とその関保について一. 日泌尿会誌，67, 
968-986, 1976.

27）重松 俊：膀胱腫瘍に於ける染色体数の意義. 日 泌尿会誌，55，734-737，1964.

28）嶺井定一：膀脱腫瘍に於ける染色体の研究. 泌尿 紀要, 11，1085-1113，1965.

29）長山忠雄：染色体よりみた化学療法. 日泌尿会誌, 63, 737-738, 1972.

30) Falor, W.H. and Ward, R.M. : DNA banding patterns in carcinoma of the bladder. J.A.M.A., 226, 1322-1327, 1973.

31) Falor, W.H. and Ward, R.M.: Cytogenetic analysis: A poterntial index for recurrence of early carcinoma of the bladder. J. Urol., 115, 49-52, 1976.

32) Falor, W.H. and Ward, RLM. : Prognosis in early carcinoma of the bladder based on chromosomal analysis. J. Urol., 119, 44-48, 1978.

33) Summers, J.L., Falor, W.H. and Ward, R.M. : A 10-year analysis of chromosomes in noninvasive papillary carcinoma of the bladder. J. Urol., 125, 177-178, 1981.

34) Spooner, M.E. and Cooper, E.H.: Chromosome constitution of transitional cell carcinoma of the urinary bladder. Cancer, 29, 1401-1412, 1972.

35) Esposti, P.L. and Zajicek, J. : Grading of transitional cell neoplasms of the urinary bladder smears of bladder washings. Acta Cytologica, 16, 529-537, 1972.

36) Rübben, H., Bubenzen, J., Bökenkamp, K., Lutzeyer, W. and Rathert, P.: Grading of transitional cell tumors or urinary tract by urinary cytology. Urol. Res., 7, 73-91, 1979.

37) Heney, N.M., Szyfelbein, W.M., Daly, J.J., Prout, G.R. and Bredin,H.C. : Positive urinary cytology in patients without evident tumor. J. Urol., 117, 223-224, 1977.

38）態登宏光, 根本良介, 加藤哲郎：尿細胞診の臨床的 意義. 臨泌，35，469-473，1981.

39）坪井成美, 秋元成太, 失崎恒忠, 由井康雄, 中島
均, 戸塚一彦, 川井 博: 尿細胞診の臨床統計. 臨 泌, 33，469-474，1979.

40）林田重昭, 桐山旁夫, 山本憲男, 平山 嗣：尿剝離 細胞診の臨床的価値. 癌の臨床, 19, 482-487, 1973.

41）牧野佐二郎：染色体一人類の細胞遺伝一. 第 1 版. p. 129）医学書院，東京，1979.

42) Dewald, G., Dines, D.E., Weiland, L.H. and Gordon, H. : Usefuless of chromosome examination in the diagnosis of malignant pleural effusions. N. Engl. J. Med., 295, 1494-1500, 1976.

43) Hansson, A. and Korsgaard, R. : Cytogenetical malignant pleural effusions. Scand. J. Resp. Dis., 55, 301-308, 1974.

44) Umiker, W.,Lapides, J. and Sourenne, R. : Exfoliative cytology of papillomas and intraepithelial carcinoma of the urinary bladder. Acta Cytologica, 6, 255-266, 1962.

45) Johnsonk W.D.: Cytopathological correlations in tumors of the urinary bladder. Cancer, 17, 867-880, 1964.

46) Umikler, W. : Accuracy of cytologic diagnosis of cancer of the urinary tract. Acta Cytologica, 8, 186-193, 1964.

47) Esposti,P.L., Edsmyr, F. and Tribukait, B. : The role of exfoliative cytology in the management of bladder carcinoma. Urol. Res., 6, 197-202, 1978.

48) El-bolkainy, M.N.: Cytology of bladder carcinoma. J. Urol., 124, 20-22, 1980.

49) Atkin, N.B. and Petkovic, I. : Variable sex chromatin pattern in an early carcinoma of the bladder. J. Clin. Path., 26, 126-179, 1973.

50) Sadougjhi, N., Rubenstone, A., Mlsna, J. and Davidsohn, I.: The cell surface antigens of bladder washing specimens in patients with bladder tumors, a new approach. J. Urol., 123, 19-21, 1980.

（1982年 5 月 17 日受付） 